\title{
A POESIA DE MANOEL DE BARROS: CARTOGRAFANDO TERRITÓRIOS
}

\section{Letícia Scherner $^{\mathrm{i}}$}

\section{Afetações}

Os anseios e as inquietudes são tantas nestes primeiros momentos dando a sensação de que nada se alinha, e em que nada se acerta. Escreverii é um ato doloroso, pois trata-se de desfazer de um pensamento regrado, e, tentar por o "corpo a ventos". Poder sentir de certa forma, que as incertezas fazem parte de uma vida que pulsa, as quais seguem o fluxo de possibilidades de se aventurar e colocar o pensamento na rua.

Talvez, Manuel de Barros tenha pensado em um quintal onde tudo é possível, cada um com sua subjetividade e singularidade. Uma infinita quantidade de experimentações e possibilidades ínfimas. Mistura-se a isso, a infância, ou as infâncias, a(s) qual(is) o poeta pensa e escreve as palavras que compõe de forma infinita os silêncios.

Acho que o quintal onde a gente brincou é maior do que a cidade. A gente só descobre isso depois de grande. A gente descobre que o tamanho das coisas há que ser medido pela intimidade que temos com as coisas. Há que ser como acontece com amor. Assim, as pedrinhas do nosso quintal são sempre maiores que as pedras do Mundo (BARROS, 2008, p.67).

Fomos afectadas ${ }^{\text {iii }}$ pela poesia de Manoel. Ela de certa forma nos alegra, alimenta a alma e provoca a criação, não se curva para a linearidade do pensamento. É como ele que passamos a ensaiar composições e criações com as infâncias no espaço escolarizado. Sem dúvida um desafio que escolhemos trilhar na companhia de poeta e miudezas. Nesse trajeto abrigamos na mala o seguinte problema: de que modo às sutilezas do devir infantil podem ser cartografadas em um espaço escolarizado? A intenção da pesquisa é de realizar junto com as crianças a invenção de mundos cartografando o espaço escolar pelas lentes da máquina fotográfica. Capturar flashes, invisíveis aos olhos no espaço escolar, por se tratar de um ambiente em que passam a maior parte do tempo, mas que muitas vezes não percebem a singularidade das miudezas e das sutilezas ali presentes.

Há outras maneiras de pensar a(s) infância(s) na escola? Como podemos observar atentamente as expressividades e subjetividades de cada um? Questões que norteiam a pesquisa num sentido de qualificar tal processo sem distinção de resultados e, tampouco definições acerca do conceito de infância. 
Assim como a criança, a poesia do Manoel de Barros deixa rastros para pensar sobre uma infância da incompletude. É como degustar o sabor indefinido. Escolhemos a cartografia, como método de pesquisa que através de pistas orientarão o trabalho, a qual considera o processo, o objeto de pesquisa, e o pesquisador com os resultados (PASSOS E BARROS, 2009). "Fugindo dos processos formais, o cartógrafo mergulhado na sua pesquisa, se ocupa dos caminhos errantes, estando suscetível a contaminações e variações produzidas durante o próprio processo de pesquisa" (COSTA, s/a, p.5).

A cartografia enquanto espaço para compor com as experiências de vida. Investigar territórios inalcançáveis e inexplorados. É estar em constante movimento, ou até mesmo, em micro-movimentos, mas que de alguma forma impulsiona e inquieta o pensamento. Conforme $\operatorname{Costa}(\mathrm{s} / \mathrm{a})$ :

[...] a vida é feita de segmentações, que somos segmentados por todos os lados e direções, em linhas que pertencem a todos os estratos que compõem o viver. Quando falamos de linhas estamos falando de forças, estas vindas dos mais diferentes espaços e situações: linhas sociais, econômicas, afetivas, institucionais, fabulatórias, memoriais, etc. (p.3)

Pensando em linhas, retas, turvas, semi-abertas, ou seja, uma infinidade de traços que podemos percorrer, a cartografia é criação, sendo assim, uma possibilidade para entender as diferentes formas de pesquisar. Um caminho de possíveis, para poder escolher rotas, construindo geograficamente as ruelas e os becos. Cartografar é desenhar no mar, movimentar-se com as ondas, em um vem e vai de possibilidades. (FONSECA E KIRST, 2003). Uma fonte inesgotável de trajetos que, podem ser reinventadas. Tecidas por entradas e saídas, que convocam a experimentação inflamando as verdades únicas e absolutas.

\section{Lugares da infância}

Momentos que nos desprendemos do eu (identidade), para cavar territórios aerados à liberdade momentânea. Impulso! Isso mesmo. Ter força nos pés, o vai e vem do balanço. Posso tocar as nuvens? Salarê ,minguê, o sorvete colorê, feitos de gliter? Algodão? Anjos que brincam no céu?" (DIÁRIO DE CAMPO, 19/05/13).

A vida permite pausas e um caminhar desacelerado. Passos e descompassos de uma dança nova, cantarolar, as vozes soltas em notas desmioladas e sem afinação. Jódar (2002) destaca:

Os arredores. Ali, onde, ao andar, as pessoas se requebram e fazem ginga; onde, para não topar nas cantoneiras, elas, cantando e dançando, desviam-se e inventam 
passos. É um espaço de finta e de balanço. Nos seus arredores tudo se desformaliza, não se segue reto nem correto, mas também não se chega ao caos total. Tampouco é lugar de palavra unívoca (p.37).

Habitamos um mundo cercado pelas diferenças, arbitrariedades e mutações. Na Idade Média, as crianças permaneciam a maior parte do tempo com os adultos, juntamente com os pais, trabalhavam e participavam de jogos. Não havia o momento íntimo, era muito mais um coletivo de ações. Uma época onde a família primava pela posse. A criança, não se diferenciava dos adultos, vestia-se com adultez, a infância era uma época difícil, com uma alta taxa de mortalidade (ARIÉS, 1981).

A infância permite ousadia, causa efeitos colaterais sem medo. Enaltece por sua exuberância e surpreende a cada encontro. Em diferentes lugares, nos encontramos de braços abertos àquilo que pode afetar e potencializa o pensamento. A primeira delas foi feita após um banho quente, onde as interrogações sobre o problema de pesquisa pareciam jorrar.

Os lugares da infância, tantos quantos possiveis de se achar. Não demarcados pelo tempo e espaço. Infâncias sem moldes e etapas distante e indiferente a cronologia que impõe o tempo de um relógio (DIÁRIO DE CAMPO, 30/04/2014).

Partimos de que todo o ser humano nasce, cresce, se desenvolve, experimenta, amadurece e algum dia morre. O morrer poderia aqui estar definido como o fim da vida humana na terra, mas também, na possibilidade que temos em nos desprender para nos movimentar a outros horizontes incitando a experimentação de outras vivências. A importância do ser, na existência das coisas, sejam elas grandes ou pequenas, está na simplicidade em que elas causam. Dominar saberes, estratégias e resultados. É isso que as pessoas estão acostumadas a fazer no seu dia-a-dia. Prestar atenção a essa "gente pequena", que vislumbra os lugares por onde passam soltas, livres, capazes de sensibilizar o nada com sua incompletude. (DIÁRIO DE CAMPO, 02/04/14). iv

Liliana Sulzbach em seu documentário “A invenção da infância” (2000), apresenta uma imagem de infância frágil e inocente numa contraditória representação dos dias atuais, uma sociedade que prioriza o consumo e explora o trabalho infantil. No livro, História Social da Criança e da família, Philippe Ariès aponta:

Até por volta do século XII, a arte medieval desconhecia a infância ou não tentava representá-la. É difícil crer que essa ausência se devesse à incompetência ou à falta de habilidade. É mais provável que não houvesse lugar para a infância nesse mundo (p.17). 
A fronteira entre o adulto e a criança está desaparecendo estamos adeptos e inseridos em uma sociedade contemporânea que não controla mais a informação e tampouco os processos de aprendizagem. A infância não é mais da inocência, privada de informações, ela está exposta, pela mídia e pelo contato com o mundo com maior liberdade. Díaz (2010) aponta para o esfacelamento da infância:

Seja o desaparecimento da infância, seja o desenho de outro mundo infantil, com qualidades diferentes, o que parece evidente é que a infância como noção está se deslocando. Contudo, tal ocorrência não se encontra associada à visão de progresso, desenvolvimento ou evolução, mas sim ao acontecimento de um conjunto de práticas concretas de adultos e crianças em contextos históricos e culturais específicos (p.198).

A morte da infância poderia então estar associada a todas essas tentativas de compreendê-la como uma etapa enrijecida e sem possibilidades de "transver o mundo" (BARROS, 1996, p.51).

Nada como sentir o cheiro da terra que molha lentamente o chão. A grama ao ser cortada, a pipoca que estoura na panela, e o brigadeiro que se come de colher. E quando isso acontece, é como se estivéssemos revendo um filme, cenas que se prolongam em cenários diversos (DIÁRIO DE CAMPO, 30/04/2014).

Ah! como é bom ter infância! Detalhes minuciosamente escondidos e esquecidos nessa vida adulta. Ela não morre. Ela ecoa numa proporção de longa escala. Mas quais são as etapas que deve haver uma infância? Uma padronização perderia totalmente o sentido. Então, sejamos sensatos o suficiente para perceber que ela pode durar o tempo necessário para ser inesquecível (DIÁRIO DE CAMPO,19/04/14).

A infância se ocupa de diferentes lugares. Seria injusto delimitar apenas um lugar. "Talvez a infância, assim como a poesia, não precise ser analisada, mas sentida. "Sofro medo de análise", afirma o poeta Manoel de Barros. "As crianças parecem repeti-los em segunda voz." (KOHAN, 2004, p.22) .

Kohan (idem):

Diversos trabalhos contemporâneos afirmam outros conceitos e outros lugares para a infância. Dentre eles, G. Agamben mostra como a infância é, antes de uma etapa, uma condição da experiência humana (2001, p.5s). [...] Agamben esclarece que ela indica uma condição: infância é tanto ausência, quanto busca de linguagem, só um infante se constitui em sujeito da linguagem e é na infância que se dá essa descontinuidade especificamente humana entre o dado e o adquirido, entre a 
natureza e a cultura. O ser humano é o único animal que aprende a falar, e não poderia fazê-lo sem infância (p.54).

Muito cuidado porque não queremos generalizar a infância, o infante (aquele que não fala) que passa por ela, deixa um pouco de si e também carrega um tanto de cada experiência. Dos lugares em que ela possa estar, poderíamos enumerar, ou então, quantificar, porém preferimos deixar em suspensão as quantidades, assim como qualquer tipo de relação que isso possa vir a ter com fases, etapas ou ciclos. Nosso interesse é pegar carona na rima e na poesia que desconcentra a razão.

\begin{abstract}
Como conhecer jamais o menino? Para conhecê-lo tenho que esperar que ele se deteriore, e só então ele estará ao meu alcance. Lá está ele, um ponto no infinito. Ninguém conhecerá o hoje dele. Nem ele próprio. Quanto a mim, olho, e é inútil: não consigo entender coisa apenas atual, totalmente atual. O que conheço dele é a sua situação: o menino é aquele em quem acabaram de nascer os primeiros dentes e é o mesmo que será médico ou carpinteiro.Enquanto isso - lá está ele sentado no chão, de um real que tenho de chamar de vegetativo para poder entender. Trinta mil desses meninos sentados no chão, teriam eles a chance de construir um mundo outro, um que levasse em conta a memória da atualidade absoluta a que um dia já pertencemos? A união faria a força. Lá está ele sentado, iniciando tudo de novo mas para a própria proteção futura dele, sem nenhuma chance verdadeira de realmente iniciar. Não sei como desenhar o menino. Sei que é impossível desenhá-lo a carvão, pois até o bico de pena mancha o papel para além da finíssima linha de extrema atualidade em que ele vive (LISPECTOR, 1969, s/p, JORNAL DO BRASIL).
\end{abstract}

E nessa linha, não linear que nos propomos a habitar, importa às minúsculas partículas que podem atribuir sentido aquilo que não percebemos a olho nu. Despidas de verdades, desejamos unhas afiadas que se lancem a cavar a terra dura, provocando fissuras, memórias inventadas, esquecimentos, invenções e afetamentos, é por esses movimentos que prezamos.

\title{
O poeta do anonimato
}

E agora o que fazer com essa manhã desabrochada a pássaros?

(BARROS, 2004).

Manoel de Barros é um poeta que começou a publicar desde a década de 30, mas começou a ser reconhecido somente a partir da década de 80. Algumas de suas obras: Poemas concebidos sem pecado (1937); Face Imóvel (1942); Arranjos para Assobio (1980); Concerto a céu aberto para solos de ave (1991); Memórias Inventadas (2008). Mesmo com essa vasta biblioteca, ainda tem um público específico. Diria até mesmo que muito seleto.

No poema Cabeludinho(1996), ele conta um pouco a sua história: 


\author{
Sob o canto do bate-num quara nasceu Cabeludinho \\ Bem diferente de Iracema \\ Desadando pouquíssima poesia \\ o que desculpa a insuficiência do canto \\ mas explica a sua vida \\ que juro ser o essencial \\ -Vai desremelar esse olho, menino! \\ -Vai cortar esse cabelão, menino! \\ Eram os gritos de Nhanhá (BARROS,1996, p.7).
}

É Manoel ainda pequeno, dando seus primeiros passos. Fala da escola, e quando foi descoberto como poeta:

\author{
No recreio havia um menino que não brincava \\ Com outros meninos \\ O padre teve um brilho de descobrimento nos olhos \\ -POETA! \\ O padre foi até ele: \\ - Pequeno, por que não brinca com seus colegas? \\ -É que estou com uma baita dor de barriga desse feijão bichado. \\ (IDEM, p.10).
}

Fala da infância com facilidade. Quem tenta descobrir seus inventos não consegue tamanha a sua vivência e expressividade com as palavras. Sua poesia foi feita para não ser da ordem do entendimento. Não se sabe se noventa por cento é invenção, ou dez por cento é mentira.

Escrever sobre o nada, ou sobre os restos é como inventar objetos. Dar sentido a coisas. Ver talvez que uma cadeira é muito mais do que somente sentar. A poesia de Manoel de Barros é enganar-se com as próprias prosas. "Invenção serve para aumentar o mundo". (BARROS, 2008.) A infância, poesia e a literatura soam com uma singularidade plural como diria Manoel. Uma afeição por empatias.

\footnotetext{
Eu tenho um ermo enorme dentro do olho. Por motivo do ermo não fui menino peralta. Agora tenho saudade do que não fui. Acho que o que faço agora é o que não pude fazer na infância. Faço outro tipo de peraltagem. Quando criança eu deveria pular muro do vizinho para catar goiaba. Mas não havia vizinho. Em vez de peraltagem eu fazia solidão. Brincava de fingir que pedra era lagarto. Que lata era navio. Que sabugo era serzinho ma resolvido e igual a um filhote de gafanhoto. Cresci brincando no chão, entre as formigas. De uma infância livre sem comparamentos. Eu tinha mais comunhão com as coisas do que comparação [...] (BARROS, 2008, p.187).
} 
Misto de sentimentos e de vozes. Manoel é um artista contemporâneo que foge da poesia convencional.

\title{
Um manoelês feito de barro
}

A poesia de Manoel de Barros é como um punhado de barro que pode ser colocado em qualquer ambiente, algo inacabado, um reencontro entre o ser e o existir. Neto (1997) salienta a infância que aparece nas obras de Manoel de Barros:

Vale lembrar que ela vai fazer de sua poesia uma revivescência dos mitos da infância. Uma das características mais marcantes de sua poesia é que ele chama de molecular o idioma, ou seja, usá-lo de forma não-lógica. Aqui o sentimento de perda é o drama inicial que vai definir futuras opções do poeta (p.8).

Em sua obra intitulada "Memórias Inventadas", o poeta, faz uma alusão com as palavras e com tudo o que podemos inventar. O título já é uma metáfora, o qual o poeta se utiliza para referir-se a lembranças, pode ser dele ou que meramente não passou de um invento, uma arte de se propor a criar ou recordar. Ele escreve para deixar uma ordem do inquestionável, não pretende ser compreendido.

As palavras e a infância sendo potencializadas com o infante. Um jogo de combinações e expressões do imaginário. O leitor mergulha nas escritas e acaba "sujando-se". "Barros e as crianças encontram-se em um espaço indefinido onde características humanas, vegetais, animais, e minerais fundem-se." (KOHAN, 2004). Uma leitura que afeta e transporta a outros territórios.

A criança tem características próprias de reinventar-se. Manoel de Barros coloca em conflito a palavra e o sentido em que ela pode ter a todo o instante.

Larrosa (2010):

\begin{abstract}
Não obstante, e ao mesmo tempo, a infância é um outro: aquilo que sempre além de qualquer tentativa de captura, inquieta a segurança de nossos saberes, questiona o poder de nossas práticas e abre um vazio em que se abisma o edifício bem construído de nossas instituições de acolhimento. Pensar a infância como um outro é, justamente, pensar essa inquietação, esse questionamento e esse vazio. É insistir uma vez mais: as crianças, esses seres estranhos dos quais nada se sabe, esses seres selvagens que não compreendem a nossa língua (p.184).
\end{abstract}

A criança é um ser estranho e que ao mesmo tempo nos parece tão familiar. A infância moderna em conjunto com o presente, passado e futuro. Um devir que impulsiona o 
ser no seu mais marcante viver. "É preciso pensar o devir criança enquanto átomos de infantilidade, que produzem uma política infantil (desta vez, sim) molecular, que se insinuam nos afrontamentos molares de adultos e crianças". (Corazza, 2003, p.101)

Diante disso, as relações entre adulto e criança sempre se manifestaram com muita intensidade. Uma pela dependência que o infante tem nos seus primeiros meses de vida, e também pelos laços de afetividade que são construídos ao longo de sua vida, em diferentes contextos. A infância é feita de memórias, que potencializam a sua existencialidade.

Manoel nasceu com uma anomalia incurável, nasceu poeta. Com um lápis e um bloquinho, fez versos e criou um mundo. Adentrar a esse universo de dialeto Manoelês, absurdo e paupável, afeta e embaralha os sentidos. É sentir o cheiro das cores, ouvir os passos das palavras, tocar na sonoridade de cada palavra. "Poesia é o belo trabalhado." Seu trabalho é realizado em letra miúda, em um quarto pequeno em décadas de trabalho, (no lugar de ser inútil). Ele esboça o deslimite das coisas, vai além do que podemos imaginar e pensar. Também chama a atenção para o ínfimo, o pequeno, o que não vemos. "Só as coisas rasteiras me celestam." "O olho vê, a lembrança revê e a imaginação transvê". O poeta tem o dom de transformar as coisas através da palavra. Ver coisas que não existem, ser um vidente (BARROS, 2008).

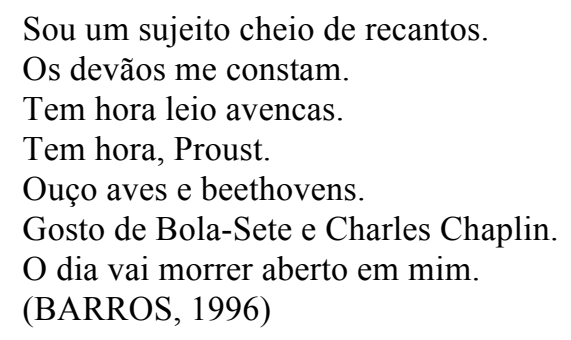

Mas o que as crianças e o poeta têm em comum? Tudo e nada. A simplicidade de encantar pela pureza em tocar as palavras e por ser infante na sua mais tenra idade. Manoel de Barros, não deixa rastros de sua vida, sua biografia é confusa, uma traquinagem pura. Sua infância ecoa nas linhas em que escreve os devires de um invento inacabado.

Os devaneios estão a todo momentos intrínsecos nas linhas abertas de sua poesia. Ela se alimenta do imaginário, as lembranças são a alma inspiradora para escrever, uma mescla do passado, é marcante e forte, evoca o eu memorial. (LINHARES, 2006). Se assemelha a uma criança que mergulha no universo linguístico, desinibida com as palavras. Ou até mesmo aquela que ainda não nasceu. Viver entre essa linha divisória, um divisor de águas, sou o que sou, ou posso ser que eu era. Metade de mim lembra-se das tardes em meio as panelinhas e bergamoteiras, outra metade se lambuza em recordar o gosto do algodão doce. Somos feitos 
de metades? O mundo que nasce na infância, um mundo poético, "no anseio de dar continuidade a esse olhar divergente, que se vale de uma maneira modificada de percepção, é que se move Barros" (LINHARES, 2006. s/p).

Acreditamos que Manoel e a cartografia têm muito em comum, são caminhos que fogem de explicação, não tendem a uma razão, pois ambos acolhem o sentir. Quem usar a poesia de Manoel e a cartografia deve ser um bom ouvinte, estar à espreita, enxergar mundo à fora desperdícios. Porque toda criança tem um mundo imaginário, ou vive em um. Seria um mundo do devir poético, então. Isso que definiria o caminho é o abandono deste universo para a vida adulta (NETO, 1997).

\title{
O devir e uma infância potente
}

O devir enquanto difusão de um olhar para além da rotina que nos cerca. Sem demarcações e propósitos de uma prática de resultados. O devir nos remete no tempo grego, aión, chrónos e kairós. Chrónos designa a temporalidade cronológica, basicamente demarcada pelo passado, presente e futuro de uma pessoa. (KOHANN, 2004.)

Ainda sobre a temporalidade grega, Kohann (idem) reafirma:

\begin{abstract}
Mesmo que chrónos tenha sido a palavra mais bem-sucedida e comum entre nós, não é a única para designar o tempo. Outra é Kairós, que significa "medida", "proporção", oportunidade. (Liddell e Scottt, 1966, p.859). Uma terceira palavra é Aión que designa, já em seus usos mais antigos, a intensidade do tempo da vida humana, um destino, uma duração, uma temporalidade não numerável nem sucessiva, intensiva (id., ib., p.45) (p.54).
\end{abstract}

Quais são as infâncias que nos interessam? Em que tempo vivemos?

Não buscamos nenhum método que nos aponte o que é certo ou errado, nem tampouco nos ocupamos em pensar a melhor ou pior infância. O que queremos enquanto pesquisadoras é olhar com outros olhos, estar atenta a este tempo intenso, sem a presença de moldes. Porque o que importa é a infância que brinda no tempo aiônico, nômade de saberes e estratégias, questiona, dança, brinca, está em todos os lugares possíveis sem delimitações. Pousamos as lentes no território da infância, para o tempo do devir que desenha geografias.

Caminhava na avenida com os fones de ouvido. Escutava as músicas, e no ritmo delas preenchia os passos. Largos, com pressa. Então vi uma família reunida em torno de uma criança de mais ou menos três anos. Ele, na sua bicicleta de rodinhas e uma menina com mais ou menos 5 anos, que também havia bicicleta mas, sem as rodas. A menina estava 
insegura, um familiar a segurava, dava impulsos para que a mesma pudesse percorrer pequenos espaços. Ainda com medo a menina colocava os pés sobre o chão. E o garoto corria o mais rápido que podia, pois sabia que estava firme, tinha base, queria apenas alcançar os demais (DIÁRIO DE CAMPO, 30/04/2014).

Continuei...mas aquela cena me fez pensar muito em tudo que estou passando e principalmente no andamento da minha pesquisa. E de certa forma, sobre as incertezas, os caminhos errantes, e o compromisso que tenho comigo mesma (DIÁRIO DE CAMPO, 30/04/2014).

Mas também, me fez pensar sobre o devir e a bicicleta. O exato momento em que o pé vai de encontro ao pedal, e o movimento do mesmo, proporcionam grandes emoções e uma oportunidade de sentir no vento que toca no rosto. Não é cronometrado, muito menos planejado, apenas apreciado, e a cada nova pedalada, outros pensamentos me invadem, não pedindo sequer licença. (DIÁRIO DE CAMPO, 30/04/2014).

Kohann (2004):

Somos habitantes dos dois espaços, das duas temporalidades, das duas infâncias. Uma e outra infância não são excludentes. As linhas se tocam, se cruzam se enredam se confundem. Não nos anima a condenação de uma e a mistificação da outra. Não se trata, por último, de dizer como há que se educar as crianças. A distinção não é normativa, mas ontológica e política. O que está em jogo não é o que deve ser (o tempo, a infância, a educação, a política), mas o que pode ser (pode ser como potência, possibilidade real) o que é (p.63).

"Capturar o silêncio", "Esticador de horizonte", enfim são "inutilidades" que talvez nos façam ver que de alguma forma as inspirações de Manoel de Barros causam efeito nesse tempo integral, sólido do aqui e agora. O tempo aiônico é o encontro entre pessoas, o movimento, os signos e o acontecimento. Não há como imitar um devir. Para Deleuze (1995):

Devir é jamais imitar, nem fazer como, nem ajustar-se a um modelo, seja ele de justiça ou de verdade. Não há um termo de onde se parte, nem um ao qual se chega ou se deve chegar. Tampouco dois termos que se trocam. A questão "o que você está se tornando"? é particularmente estúpida. Pois à medida que alguém torna se torna, o que ele se torna muda tanto quanto ele próprio. Os devires não são fenômenos de imitação, nem de assimilação mas de dupla captura, de evolução não paralela, núpcias entre dois reinos (p.10).

Os devires são compostos de "entre" e de "meio". Movimentos capazes de acontecer com um piscar de olhos, com uma fração de segundos, os devires de ser e estar.O tempo aión, seriam as linhas de fuga, criando sempre um novo meio. Habitamos essas temporalidades, vivemos de forma cronológica e também com a intensidade de estar em devir minoritário. 
(KOHANN, 2004). O devir não é de certa forma identificação, imitação, mas achar parentescos e indiferenças, para distinguir-se uns dos outros. (DELEUZE, 1995)

O poeta Manoel de Barros através da escrita tem a arte da criação, dá liberdade para inventar novas brincadeiras, que deslizam pela alegria de viver e pelas travessuras que acompanham os imprevisíveis trajetos. Uma poesia mágica certamente, que leva a infância as linhas do acontecimento e do devir, potencializa o detalhe, o ínfimo e o menor. (OLEGÁRIO, 2012).

\section{Ensaios cartográficos}

A cartografia é apresentada neste trabalho como um método de pesquisa capaz de rastrear a leveza do olhar da infância, a qual deixa brechas para o estranho, induz, lançando o olhar para intervir nesse processo. (PASSOS, 2009). Potencializamos as dúvidas sem a pretensão de encontrar uma resposta definitiva, portanto, percorremos caminhos desconhecidos, tendo a possibilidade de localização com a bússola que acompanha os fluxos do devir.

Mergulhamos em experiências inseparáveis das forças que constitui a nossa subjetividade. Trocas, contatos, manejos, viagens, lugares, silêncios. Capturas nossas, internas, profundas, que são mobilizadas e tensionadas pela inquietude de ser desarranjador das coisas. O cartógrafo é um amante dos acasos. Nesse sentido, aceita os riscos desarrumando os inicios, cria os meios, as passagens e as atmosferas. Aposta no entre ${ }^{\mathrm{v}}$, ensaia traços, provocando conjunções inesperadas.

\footnotetext{
Cartografar remonta a uma tempestade... Tempestade de escolher rotas a serem criadas, constituir uma geografia de endereços, de registros de navegação, buscar passagens... Dentro do oceano da produção de conhecimento, cartografar é desenhar, tramar movimentações em acoplamentos entre mar e navegador, compondo multiplicidades e diferenciações (FONSECA, 2003, p.91).
}

Agencia-se com a vida, para descriar o realidade dada, a cada encontro é nutrido tomado por outra sensibilidade. Trata-se muito mais de sensações, entre o cartógrafo e o objeto. E nesse vai e vem de ondas, que forçamos e forjamos o pensamento para que possamos raspar as verdade da infância.

Um mar de "fueguitos" Como disse Eduardo Galeano em seu documentário "Não somos iguais". Deveras, tenho que concordar tamanho as angústias que sinto pelo trajeto que venho percorrendo. Algumas pessoas tendem a me entender, outras não. Mas tem algo que me 
acalma, a música e a poesia. Fazem com que esses turbilhões de medos, invasores das minhas noites mal dormidas, se vão ao um simples tocar, sentir, ouvir. (DIÁRIO DE CAMPO, 13/05/2014).

Uma vez iniciando as escritas em papel, computador para tecer versos, ou então simples frases. O que move um cartógrafo? O desejo. É tocado por algo, que nem ao menos sabe o porquê. Os corpos dizem muito nesse processo. É o pulsar, a pele que repele os sentimentos e afetos. (ROLNICK, 2006). A cartografia pensada como máquina, que faz os sujeitos envolvidos no processo, tem a possibilidade de modificá-lo através das experiências e subjetividades. (FONSECA, 2003)

Fonseca (2003):

Na pesquisa cartográfica, o tempo pulsa, pois se evidenciam os modos pelos quais os sujeitos percebem, experimentam e narram a passagem do tempo em suas próprias vidas e naquilo que estudam. Por este motivo, o conhecimento desde o momento de produção não pode ser tomado como algo genelarizante, mas singularizante e único (p.99).

O tempo pensado fora da lógica cronológica é se sujeitar se sujar A pesquisa é vivenciada, não permite ensaios. A atenção é uma das principais fontes inesgotáveis de que o cartógrafo necessita. Pistas que sinalizam o percurso, jamais estanque, nunca se tratam de uma mesma paisagem.

A vida é feita de encontros e desencontros. "Por onde andei" (isso até me fez lembrar da música do Nando Reis...risos... no meu quarto... com pijama Com quem cruzei, o que vivi? Faz parte de mim. Aonde eu quero estar no ano que vem? Na parede do meu quarto eu colo fotos, de pessoas das quais eu gosto. E há algumas semanas eu tive o prazer de receber cartas de amigos queridos da EPE-Bogotá. Sinto ainda o cheiro das "calles" (ruas), escuela (escola), e do tinto (café). Lembranças. Doces Recuerdo (DIÁRIO DE CAMPO, 14/05/2014).

\section{Aos olhos de um cartógrafo}

O que caracteriza um cartógrafo? Talvez pudesse arriscar algumas respostas. Caminhar e percorrer situações conforme o dia, a cor e a intensidade. Se não estivermos conectados, entregues, é bem provável que deixamos de nos afetar. Situar-se num campo geográfico, perceber uma extensão territorial de solo, pontos cartesianos, latitudes, longitudes, culturas, linguagens, capturas, conquistas. Uma pista: o cartografo "não coleta dados; ele os produz. Ele não julga; ele coloca em questão as forças que pedem julgamento.” (COSTA, s/a). 
Deleuze (1998):

Nunca é o início ou o fim que são interessantes; o início e o fim são pontos. O interessante é o meio. O zero inglês está sempre no meio. Os estrangulamentos estão sempre no meio. Está-se no meio de uma linha, e é a situação mais desconfortável. Recomeça-se pelo meio (p.52).

Há certos hábitos que são íntimos e peculiares. Temos que dilacerar as comodidades. É uma mudança interior, de dentro para fora, que, reflete acerca do que vê, sente, lê, escreve e escuta. Não há julgamento maior do que a impressão sobre nós mesmo. Bem provável que terá dias em que nada acontecerá. A quantidade não define a qualidade de uma boa cartografia.

Quanto barulho cabe dentro de um silêncio? Por mais que eu queira e tente dentro de mim soam trombetas, buzinas, vozes e cenas. Deitada na minha cama. Tudo quieto, os olhos cansados se entregam. Silêncio! Sshh! Si-lên-cio! (DIÁRIO DE CAMPO, 19/05/2014).

A cartografia não estará pronta, a ideia é praticá-la quantas vezes for necessário, em momentos específicos. Cabe o trabalho incessante de extrair os elementos dessa rede de dispositivos $^{\mathrm{vi}}$ para permitir que outras forças me afetem. Fugir é exatamente isso, sair do eixo, ou as zona de conforto. São viagens em rotas curtas e longas, durações intermináveis, poder estar aqui e ali ao mesmo tempo. Próximo a pessoas e coisas. E enquanto eu estiver estática, estou fugindo. "Uma fuga é uma espécie de delírio. Delirar é exatamente sair dos eixos (como “pirar" etc). Há algo de demoníaco, ou de demônio em uma linha de fuga." (DELEUZE, 1998, p.53).

É um diário de bordo, que criamos territórios de pesquisa. Como aponta Olegário (2011):

Cruzamentos formados por inúmeras inquietudes foram escritas no diário de campo, que é utilizado por mim enquanto recurso metodológico da pesquisa. Esta forma de anotação escrita é pensada a partir da noção do dispositivo, cujo movimento de escrever, ler e pensar possibilita acompanhar e acolher novos encontros tecidos na experiência, que vão dando o tom, o ritmo e a musicalidade à pesquisa (p.34).

Desejos incuráveis que se fundem a ideias inacabadas, mas que de alguma forma impulsionam a um prazer fulgaz.

O desejo não é, portanto, interior a um sujeito, tampouco tende para um objeto: é estritamente, imamente a um plano ao qual ele não preexiste a um plano que precisa ser construído, onde partículas se emitem. Fluxos se conjugam. Só há desejo quando 
há desdobramento de determinado campo, propagação de determinados fluxos, emissão de determinadas partículas (DELEUZE, 1998, p.105).

A escrita acontece em papel timbrado, cetim, em uma embalagem de pão ou naquele papelzinho colorido do chão. "O cartógrafo é um verdadeiro antropólogo: vive de expropriar, se apropriar, devorar e desovar, trasvalorado." (ROLNIK, 2006, p.65). Nós, como cartógrafas não temos a pretensão de encontrar a resposta, até porque a resposta não se encontra, se produz.

O céu não é o limite e para mim ele não é azul, é colorido, carregado. As direções que me orientam também me confundem. As pessoas me confundem. Sofro de psicanálises. Quando questionada sobre minha pesquisa, as caras e bocas são inevitáveis. Não sei exatamente se alguém percebe o tanto quanto ela é desprovida de qualquer entendimento em primeira instância. Escrevi sem pudor, com alma desprovida de medos. Tive receios, mas que de certa, fizeram eu me entregar de corpo aos escritos e as miudezas de cada linha. (DIÁRIO DE CAMPO, 04/06/2014).

\section{Referências bibliográficas}

A INVENÇÃO da infância. Youtube. Disponível em: $<$ http://www.youtube.com/watch?v=AaSQ7HeUugU>. Acesso em: 24 abr. 2014. ARIÉS, Philippe. História Social da Criança e da Família. Rio de Janeiro: LTC EDITORA, 1981.

BARROS, Manoel de. Memórias Inventadas: as infâncias de Manoel de Barros/iluminuras de Martha Barros. São Paulo: Editora Planeta do Brasil, 2008. . Livro sobre o nada. Biblioteca Manoel de Barros [coleção]/Manoel de Barros. São Paulo: LeYa,1996.

Só dez por cento é mentira. 2008. Disponível em: $<\mathrm{http}: / /$ www.youtube.com/watch?v=XCMczEBuII4>. Acesso em: 4 maio 2014.

BARROS,Manoel. Poemas concebidos sem pecado.(1937) Biblioteca Manoel de Barros [coleção]/Manoel de Barros. São Paulo: LeYa, 2013.

BEDIN DA COSTA, Luciano. Cartografia: uma outra forma de pesquisar. Revista digital do LAV - vol . Setrem, 2014

BEDIN DA COSTA, Luciano. Cartografias Infantis. Setrem Faculdade Três de Maio. Aula ministrada pelo professor Luciano Bedin da Costa na Universidade Setrem. (Ano?) 
CEZAR,Claudia Zimmer de Cerqueira. Série Cartografia do Meio e Outros Meios. Porto Alegre: $\quad$ v.11, n.2, jul./dez. 2008. Disponível em: $<$ http://seer.ufrgs.br/InfEducTeoriaPratica/article/view/8119>. Acesso em: 16 maio 2014.

CORAZZA, Sandra Mara. Uma vida de Professora. Sandra Mara Corazza. Ijuí: Ed.Unijuí, 2005.

- Sandra Mara. Infancionática: dois exercícios de ficção e algumas práticas de

artifícios. In: CORAZZA， Sandra; TADEU, Tomaz. Composições. Belo Horizonte: Autêntica, 2003, p. 89-129.

DELEUZE, Gilles. Diálogos. Gilles Deleuze, Claire Parnet;tradução de Eloisa Araújo Ribeiro.São Paulo: Editora Escuta, 1998.

DELEUZE, Gilles. Mil Platôs: capitalismo e esquizofrenia. vol.4. Gilles Deleuze; Félix Guatarri. Tradução de Suely Rolnick. São Paulo: ed.34,1997.

DÍAZ, Dora Lilia Marín. Morte da Infância Moderna ou Construção da Quimera infantil? Revista Educação e Realidade, Porto Alegre, 2010. Disponível em: $<$ http://educa.fcc.org.br/scielo.php?pid=S010031432010000300012\&script=sci_arttext $>$.

Acesso em:15 maio 2014.

FONSECA, Tania Maria Galli. Cartografia e devires: a construção do presente (org). Porto Alegre: Ed.UFRGS, 2003.

GALEANO, Eduardo. Um mar de fueguitos. Disponível em: $<$ http://www.youtube.com/watch?v=DaU1Pv4u1ws.>. Acesso: 13 maio 2014.

JÓDAR, Francisco. Devir-Criança:experimentar e explorar outra educação. Revista: Educação e Realidade, julho/dezembro, 2002. Disponível em:< http://seer.ufrgs.br/educacaoerealidade/article/view/25914>. Acesso em: 22 maio 2014.

LARROSA, Jorge. Pedagogia profana: danças, piruetas e mascaradas. Texto de Jorge Larrosa, tradução de Alfredo Veiga Neto, 5.ed. Belo Horizonte: Autêntica, 2010.

LINHARES, Andrea Regina Fernandes. Memórias Inventadas: Figurações do sujeito na escrita autobiográfica de Manoel de Barros. Mestrado em História da Literatura. Fundação Universidade do Rio Grande./Julho de2006.

LISPECTOR, Clarice. Menino a bico de pena.1969. Publicado no Instituto de Psicologia. Disponível em: $<$ http://www.ip.usp.br/portal/index.php?option=com_content $\&$ view $=$ article $\&$ id $=4395 \% 3$ Aco nto-qmenino-a-bico-de-penaq-clarice-lispector-8101969\&catid=409\%3Aarquivoip\&Itemid=220\&lang=pt>. Acesso em: 31 mar. 2014. 
MUNHOZ, Angélica Vier. Diálogos na pedagogia: coletâneas. Angélica Vier Munhoz (Org.). Lajeado: Ed.UNIVATES, 2012.

NETO, Miguel Sanches. Achados do chão. Paraná: Editora UEPG. 1997.

OLEGÁRIO, Fabiane. Rastros das linhas menores de escrita. Dissertação (Mestrado). Universidade de Santa Cruz do Sul, 2011. Disponível em: $<$ http://btd.unisc.br/Dissertacoes/FabianeOlegario.pdf $>$. Acesso em: 21 maio 2014.

PASSOS, Eduardo. Pistas do método da cartografia: Pesquisa-intervenção e produção de subjetividade (Orgs). Eduardo Passos, Virgínia Kastrup e Liliana da Escóssia. Porto Alegre: Sulina,2009.

ROLNIK, Suely. Cartografia sentimental: transformações contemporâneas do desejo. Porto Alegre: Sulina, 2006.

WALTER, O. Kohan (org.) Lugares da infância: filosofia. Rio de Janeiro: DP\&A, 2004.

\footnotetext{
${ }^{\mathrm{i}}$ Univates/Lajeado-RS

ii Gilles Deleuze (1997) em seu livro Crítica e Clínica diz que escrever não é certamente impor uma forma (de ḯxpilłssãD)ekemaa ( expressão) a uma matéria vivida. Escrever é um caso de devir, sempre inacabado, sempre em via de fazer-se, e que extravasa qualquer matéria vivível ou vivida. (p.11)

iii Corazza (2005) fala que esses afectos não são sentimentos nem afetos, no sentido conhecido dos termos, mas a parte não pessoal, invisíveis dos estados subjetivos e vividos, as vidências e os devires inumanos da professora e do aluno (por isto, os afectos são escritos com a letra c) (p.90).

${ }^{\text {iv }}$ As escritas no diário de campo aparecem em todo o trabalho que segue, em letra itálica a fim de marcar o registro.

${ }^{\vee}$ Saliento algo que está entre, aquilo que está entre dois pontos. (Cezar,2008)

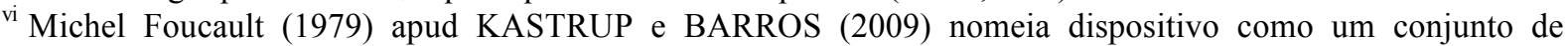
discursos, leis, enunciados, ou seja, é o que se pode estabelecer entre os elementos. (p.77)
} 